\title{
PENDAMPINGAN PENGGUNAAN MEDIA LITERASI BIG BOOK SISWA KELAS AWAL DI DESA PLUMPANG KECAMATAN SUKODADI KABUPATEN LAMONGAN
}

\author{
Ummu Khairiyah \\ Jurusan PGMI, Fakultas Agama Islam, Universitas Islam Lamongan \\ Jl. Veteran No. 53 A Lamongan \\ Email: ummukhairiyah@unisla.ac.id
}

\begin{abstract}
ABSTRAK
Kemampuan membaca di kelas awal merupakan pondasi yang penting sebagai dasar penentu keberhasilan dalam kegiatan belajar peserta didik. Jika kemampuan membaca di kelas awal tidak kuat, maka peserta didik akan sulit memiliki kemampuan membaca yang memadai. Pendampingan ini merupakan pendampingan pembelajaran bagi siswa kelas 1 MI dan SD di desa pelumpang kecamatan sukodadi kabupaten lamongan. Pengabdian ini dilakukan oleh Mahasiswa KKN BBM Universitas Islam Lamongan tahun 2019. Mahasiswa membuat media Big Book dan media puzzle menyusun kata menjadi kalimat sesuai cerita yang disajikan pada Big Book.
\end{abstract}

Kata Kunci: Media Big Book, kemampuan membaca

\begin{abstract}
The ability to read in the early grades is an important foundation as a basis for determining success in students' learning activities. If the ability to read in the early grades is not strong, students will find it difficult to have adequate reading skills. This assistance is a learning assistance for 1 st and MI grade students in Pelumpang Village, Sukodadi Subdistrict, Lamongan Regency. This dedication was carried out by Students of KKN BBM Lamongan Islamic University in 2019. Students made Big Book media and puzzle media arranged words into sentences according to the story presented in the Big Book.
\end{abstract}

Keywors: Big Book media, reading skills

\section{PENDAHULUAN}

Literasi merupakan kemampuan berbahasa seseorang (menyimak, membaca, dan menulis) untuk berkomunikasi dengan cara yang berbeda sesuai dengan tujuannya. Kemampuan literasi membaca merupakan kemampuan dasar yang harus dikuasai peserta didik karena merupakan penentu keberhasilan dalam kegiatan belajar. Apabila anak pada usia sekolah tidak memiliki kemampuan membaca, maka ia akan mengalami kesulitan dalam mempelajari berbagai bidang studi pada kelas-kelas berikutnya. 
Ada beberapa faktor yang dapat mempengaruhi kemampuan membaca siswa, baik faktor dari dalam maupun faktor dari luar. Salah satunya motivasi dan bahan bacaan, motivasi merupakan faktor yang cukup besar mempengaruhi kemampuan membaca, apabila seseorang tidak memiliki motivasi maka akan mengakibatkan enggan membaca, sedangkan yang memiliki motivasi tinggi akan memiliki dorongan yang cukup kuat untuk membaca. Bahan bacaan juga mempengaruhi minat pembaca untuk membaca. Bahan bacaan yang terlalu sulit dipahami akan membuat seseorang untuk enggan membaca.

Setidaknya faktor yang dapat mempengaruhi kemampuan membaca tersebut dapat diatasi, tentu pendampingan harus berbeda dari proses belajar-mengajar seperti di sekolah yang terkadang masih menggunakan cara-cara konvensional. Cara yang dilakukan adalah dengan membuat media pembelajaran inovasi yang dapat mempermudah dan membuat peserta didik senang dalam belajar membaca.

Menurut Schramm (1982) media pembelajaran adalah teknologi pembawa pesan yang dapat dimanfaatkan untuk keperluan pembelajaran. Gagne (1970) menyatakan bahwa media adalah berbagai jenis komponen dalam lingkungan siswa yang dapat merangsangnya untuk belajar.Miarso (2004) mengemukakan bahwa media merupakan segala sesuatu yang dapat digunakan untuk menyalurkan pesan yang dapat merangsang pikiran, perasaan, perhatian, dan kemauan siswa sehingga terjadi proses belajar. Azhar Arsyad (2007) mengatakan bahwa pemakaian media pembelajaran dalam proses pembelajaran dapat membangkitkan keinginan dan minat yang baru serta membangkitkan motivasi dan rangsangan dalam kegiatan pembelajaran.

Proses pembelajaran kelas awal memerlukan media untuk menyampaikan materi pelajaran secara maksimal, karena pada anak usia kelas awal berada dalam tahap operasional konkret. Karakteristik siswa kelas awal mempunyai rentang konsentrasi pendek sehingga membutuhkan dukungan untuk menarik perhatian terhadap yang dipelajarinya (USAID, 2014). Dalam pendampingan ini, media yang digunakan yakni media Big Book. 


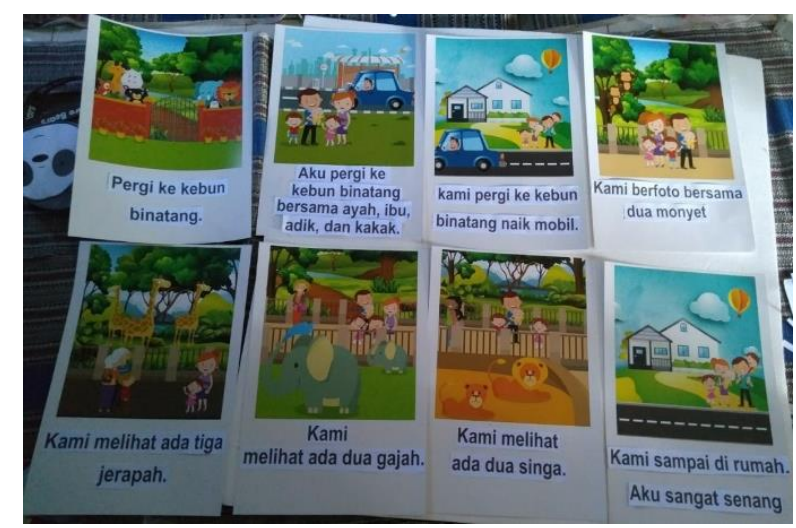

Gambar 1. Media Big Book

Media Big Book merupakan buku cerita yang berkarakteristik khusus yang dibesarkan, baik teks maupun gambarnya, sehingga memungkinkan terjadinya kegiatan membaca bersama antara guru dan siswa. Buku ini memiliki karakteristik khusus seperti penuh warna-warni, memiliki kata yang dapat diulang-ulang, dan memiliki pola teks yang sederhana Curtain dan Dahlberg (2004) menyatakan bahwa big book memungkinkan siswa belajar membaca melalui cara mengingat dan mengulang bacaan. Banyak ahli pendidikan yang menyatakan bahwa big book sangat baik dipergunakan di kelas awal karena dapat membantu meningkatkan minat siswa dalam membaca. Big book dapat dibuat sendiri oleh guru dan disesuaikan tema pelajaran. Bahkan guru dapat membuat media big book sendiri sesuai dengan karakteristik dan kebutuhan peserta didik.

Berdasarkan hasil observasi ketika kegiatan KKN-BBM Mahasiswa Universitas Islam Lamongan, diketahui bahwa masih banyak siswa kelas awal yang kemampuan membacanya rendah, akibatnya menghambat kegiatan pembelajaran yang lain. Oleh karena itu, untuk mengatasi hal tersebut, dilakukanlah pendampingan penggunaan media literasi big book siswa kelas awal di desa pelumpang kecamatan sukodadi kabupaten lamongan.

\section{METODE}

Pelaksanaan pengabdian ini dilakukan di Balai desa Plumpang kecamatan sukodadi kabupaten lamongan. Sasaran pengabdian ini yakni siswa kelas 1 Madrasah Ibtidaiyah dan Sekolah Dasar di Desa Pelumpang dengan jumlah 32 siswa. Adapun tema yang digunakan yaitu Tema 4 keluargamu, subtema 2 kegiatan keluargamu. Kegiatan yang digunakan dalam pengabdian ini berupa pendampingan, diskusi dan game. Pendampingan dilakukan dengan bentuk aksi nyata penggunaan media Big Book, 2 mahasiswa dalam hal ini berperan sebagai guru. Pada tahap awal memperlihatkan halaman judul Big Book dan menanyakan ke siswa 
untuk memprediksi isi cerita dalam big book. Guru menuliskan jawaban-jawaban prediksi siswa di papan tulis, selanjutnya guru memberikan contoh membaca Big Book dengan lafal dan intonasi yang jelas serta membacakan dengan menunjuk kata per kata dan diikuti oleh seluruh siswa.

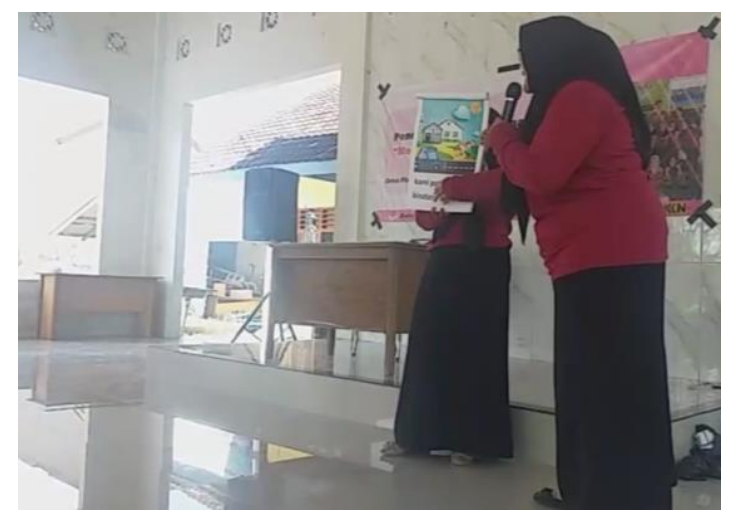

\section{Gambar 2. Guru Membacakan cerita dengan media Big Book}

Tahap kedua, guru meminta beberapa siswa secara bergantian untuk maju membacakan isi cerita yang ada di Big book seperti yang sudah dicontohkan sebelumnya. Hal ini dilakukan untuk mengetahui sejauh mana kemampuan siswa dalam membaca. Langkah selanjutnya, guru membagi siswa menjadi beberapa kelompok dan memberikan puzzle kata yang nantinya akan disusun oleh siswa berdasarkan isi cerita yang ada di big book. Hal ini dilakukan untuk mengetahui apakah siswa dapat memahami isi cerita yang tertulis dalam big book. Siswa secara berdiskusi menyusun kata sehingga menjadi kalimat yang utuh.

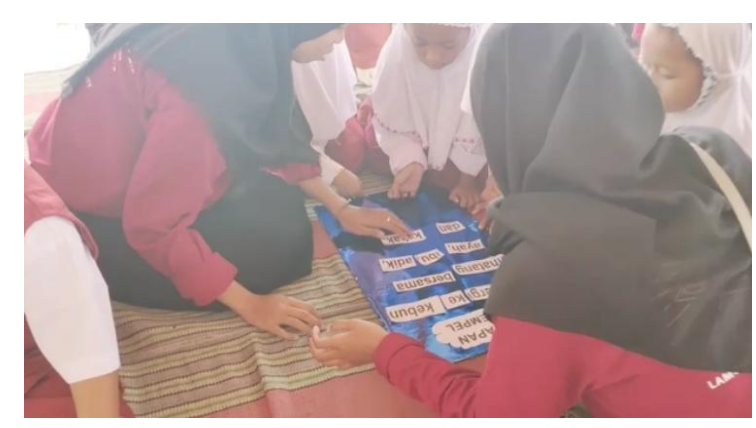

Gambar 3. Diskusi menyusun Puzzel

Tahap yang terakhir yakni melakukan game. Game dilakukan secara berkelompok. Masing-masing kelompok berbaris kebelakang. Aturan mainnya, masing-masing siswa menyusun kata dan di tempel di papan tempel yang sudah disediakan. Setiap siswa 
mempunyai tanggung jawab untuk memahami kalimat yang disusun. Siswa yang sudah menempelkan kata kembali ke barisan, selanjutnya akan dilanjutkan secara estafet siswa berikutnya hingga membentuk kalimat yang utuh dan sesuai denga isi cerita yang ada di Big Book.
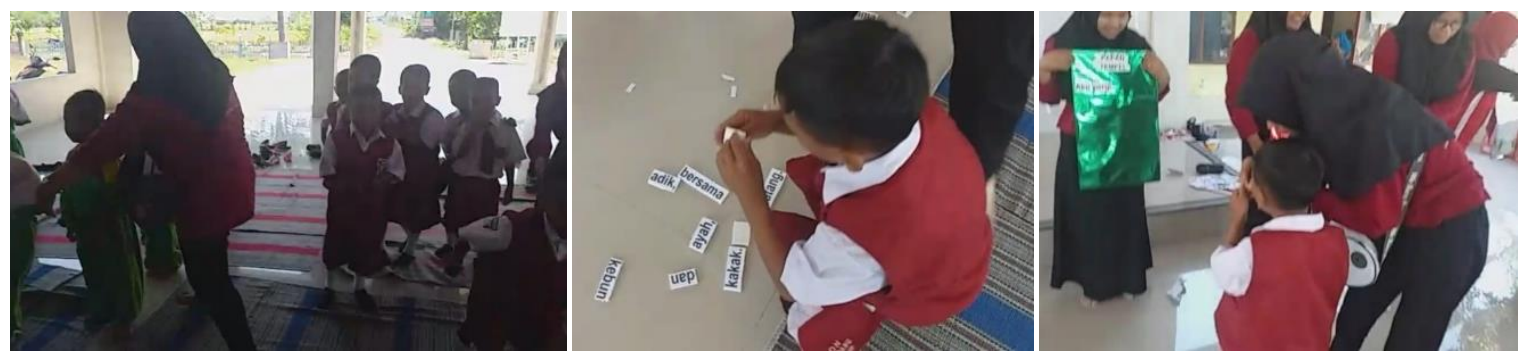

Gambar 4. Siswa semangat melakukan Game menyusun kata

\section{HASIL DAN PEMBAHASAN}

Hasil dalam pengabdian ini berupa capaian proses dalam kegiatan pendampingan yang focus pada aspek kemampuan literasi (membaca) dengan menggunakan media Big Book. Sabarti Akhadia (1993) mengungkapkan, ada beberapa factor yang dapat mempengaruhi kemampuan membaca antara lain motivasi dan bahan bacaan. Motivasi siswa untuk membaca memberikan pengaruh yang besar terhadap kemampuan membaca siswa. Siswa yang memiliki dorongan untuk membaca maka keterampilan membaca yang dimiliki baik. Hal tersebut dapat dilihat dari perhatian siswa ketika guru membacakan cerita dengan menggunakan media Big Book. Siswa yang memperhatikan guru saat memberikan contoh membaca yang benar, maka dapat dikatakan siswa termotivasi untuk memahami setiap kata dan isi dari cerita yang dibacakan oleh guru.

Faktor yang kedua yakni bahan bacaan. Bahan bacaan yang sulit untuk dipahami isinya maka mengakibatkan siswa enggan membacanya. Sebaliknya, bahan bacaan yang memuat cerita yang sederhana dan mudah dipahami maka akan menarik minat untuk membacanya. Sesuai dengan hal tersebut cerita yang dimuat dalam Big Book merupakan cerita yang singkat dan sederhana yang mudah dipahami oleh siswa kelas awal yang masih pada tahap membaca permulaan. Media Big book ini merupakan perantara untuk menyampaikan materi kepada siswa agar siswa mampu memahami materi yang disampaikan. Big Book menyajikan gambar yang berwarna-warni serta memuat cerita yang sederhana yang mudah dipahami oleh siswa.Gambar yang berwarna warni tersebut menarik perhatian siswa 
untuk membaca. Cerita yang sederhana dalam Big Book juga membuat siswa dengan mudah memahami isi cerita dalam Big Book.

Pelaksanaan pendampingan dengan menggunakan media Big Book ini memberikan kesempatan kepada siswa untuk dapat menggali informasi atau pengetahuan yang dimiliki siswa, selain itu dalam media Big Book dapat membuat siswa menjadi lebih berimajinasi sesuai dengan pengalaman yang dimiliki siswa. Penggunaan media big book membuat siswa berlatih membaca berulang-ulang, sehingga dengan membaca secara terus menerus diharapkan dapat meningkatkan kemampuan membaca siswa. Big Book juga melibatkan siswa untuk membaca dan berdiskusi bersama siswa lainnya tanpa menimbulkan resiko yang membahayakan. Menggunakan Big Book juga dapat menambah pengalaman siswa melalui bacaan yang ada dalam Big Book.

\section{SIMPULAN}

Kemampuan membaca siswa merupakan pondasi awal dalam menentukan keberhasilan dalam kegiatan belajar. Oleh karena itu, mahasiswa KKN-BBM Universitas Islam Lamongan 2019 dalam pengabdian ini mencoba mencari solusi guna meningkatkan minat baca siswa dan kemampuan membaca siswa. Pada kegiatan pengabdian ini juga memberikan informasi bahwa siswa akan memiliki minat membaca jika dalam kegiatan pembelajaran menggunakan media pembelajaran yang inovatif. Banyak media literasi lainnya yang dapat digunakan untuk meningkatkan minat baca siswa salah satunya yakni big book.

\section{DAFTAR PUSTAKA}

Arsyad, Azhar.Media Pembelajaran, Cet. III; Jakarta: Raja GrafindoPersada, 2002

Curtain, Helena and Coral Ann Dahlberg, Language and Children Making the Match: New Languages for Young Learners, (Boston: Person Education Inc.)

Sabarti Akhadiah. 1993. Bahasa Indonesia 3. Jakarta: Depdikbud

Schramm, W.., and Porter, W. E., 1982, Men, Women, Messages, And Media: Understanding Human Communication, New York: Harper and Row

USAID.2014. Buku Sumber untuk Dosen LPTK: Pembelajaran Literasi Kelas Awal di LPTK. Jakarta:USAID 